\title{
Beaver trapping in Russia and Belarus and problems of resources management
}

\begin{abstract}
Vladimir G. Safonov
ABSTRACT. In the Soviet Union experimental kill trapping (removal trapping) of Eurasian beaver began in 1960 in the Kirov region, and since 1963 the limited kill trapping was also permitted throughout Russia and Belarus. Regular trapping allowed obtaining large amounts of biomaterial, which significantly widened our knowledge on the general population ecology of beavers and on their behaviour during the under-ice period when observation is limited. The current decrease in demand for furs requires the realization of scientifically sound measures for beaver management based on ecological priorities.
\end{abstract}

KEY WORDS: Eurasian beaver, North American beaver, population dynamics, trapping regulation, management, ecosystem, Russia, Belarus.

Vladimir G. Safonov [safonov.vniioz@mail.ru], Department of Animal Ecology, Russian Research Institute of Game Management and Fur Farming, Preobrazhenskaya str. 79, Kirov 610000, Russia.

\section{Промысел бобра в России и Белоруссии и проблемы управления ресурсами}

\begin{abstract}
В.Г. Сафонов
РЕЗЮМЕ. Пробный отлов бобров капканами был начат с 1960 г. в Кировской области, а с 1963 г. был разрешен ограниченный промысел в России и Белоруссии. В связи с началом промысла стало возможным получение массового биоматериала, что существенно пополнило наши знания по популяционной экологии и поведению, особенно - в наименее доступный для наблюдений подледный период. Современное падение коммерческого спроса на пушнину требует осуществления необходимых мер по совершенствованию системы управления популяциями бобров, исходя, прежде всего, из экологических приоритетов.
\end{abstract}

КЛЮЧЕВЫЕ СЛОВА: бобр евразийский, бобр североамериканский, динамика численности, нормирование добычи, управление популяциями, экосистема, Россия, Беларусь.

Beavers (Castor fiber Linnaeus, 1758 and Castor canadensis Kuhl, 1820) are among a few animal species that played a significant role in the history of humankind, the development of vast, remote areas of Eurasia and North America, and the development of trade and economic relations on a global scale. The histories of both species are similar: they were almost exterminated by humans by the latter half of the $19^{\text {th }}$ century, and then successfully restored due to protection and active translocations in the $20^{\text {th }}$ century. Their populations are again being managed for obtaining marketable products, the regulation of their numbers in specific habitats, and maintenance of riparian ecosystems.

Apparently, the current higher population size and results of North American beaver restoration can be explained not only by the species' behaviour and life history (for example, a potentially higher reproductive rate) and wide-scale translocations throughout North America, but also by larger extant populations after human exploitation compared to the Eurasian beaver. These factors allowed the restoration of trapping in
North America earlier than in Eurasia. In the USA, Alaska in particular, contemporary beaver exploitation occurred at the beginning of the $20^{\text {th }}$ century. In Alabama, in the southeastern USA, during the mid 1900s, due to the fear of beaver damage to existing ecosystems, and damage to economically important crops and human infrastructure, it was considered necessary to implement a number of population control methods. These included drain-pipe routing, beaver-dam disruption with dynamite, and toxic gas injection into beaver houses (Owens, 1968). However, kill traps became the basic method of population regulation. A record level of trapping in 46 states in the USA, and in the Canadian provinces was reached during the 1979-1980 season with over 900,000 beavers taken (Larson \& Gunson, 1983). Kill trapping or removal trapping of the North American beaver rapidly became a controllable and effective measure of ecosystem maintenance.

At the same time Eurasian beavers existed in only a few isolated locations, primarily in Northern Europe. The peripheral state of the species within the former range and long isolation of limited populations (for 
example, less than 1000 animals in the USSR) may best explain the loss of genetic diversity and the resulting inbreeding depression. Limited trapping of beavers was permitted in the later $20^{\text {th }}$ century in Finland (since 1950's), Sweden and Norway (Lavsund, 1977).

All manuscripts and papers about beavers published in the Soviet Union in the first half of the $20^{\text {th }}$ century considered only biology, the role of beavers in the past, the history of extirpation, protection, and ways and prospects of population and range restoration. Discussion about the possibility of the economic use of the Eurasian beaver was raised actively in 1960's (Borodina, 1960; Barabash-Nikiforov et al., 1961; Safonov, 1962; Safonov \& Semyonov, 1962; Zharkov, 1962).

The main goal of this discussion period was to work out the biological basics for the economic use of Eurasian beaver, which would be suitable for the conditions existing in the country. To accomplish the task it was essential to study the experience of beaver trapping in North America and arrange experimental trapping of Eurasian beavers within selected areas. The need to manage North American beaver populations stemmed from damage caused to human economic interests and ecosystem modifications in areas with high density populations. In this case the rule proved to be axiomatic: populations at their highest densities are doomed to decline. It was considered essential to keep $30-40 \%$ of settlements and to remove the surplus during management (Parsons \& Brown, 1978). The North American experiences indicated that conditions favourable for early realization of reproduction potential are created in exploited populations (Boyce, 1981), and limited trapping of part of the stock is rational for both getting marketable products and stimulating reproduction in the population. Therefore, the experience confirmed Allee effects that the level of aggregation (as well as total density), at which there is an optimum growth and survival rate of the population, varies depending on the species and conditions, that's why both under-population (or lack of aggregation) and over-population can cause limiting effects on the population growth (Odum, 1975: 269).

There was no similar information about Eurasian beaver in spite of live-trapping for resettlement. Because of the monogamous mating system and familial social system of Eurasian beavers the possibility of settlement disintegration after trapping and relocation was high since the loss of one breeder was a serious threat. It was considered acceptable to trap only young adults (two-year old individuals) during their migration from parental families. But this could only be accomplished in well-studied populations within wildlife refuges and was impossible universally. Population management by kill trapping generally contradicts the functions and mission of nature reserves.

We organized experimental beaver kill trapping in accordance with "Glavokhota" (Hunting Department of Russian Federation) permit in the winter of 1960-1961 in the Kirov Province on the middle reach of the Belaya
Kholunitsa River (confluent of Vyatka River) where beavers were released twice: 24 animals from Voronezh (1940) and 21 animals from Belarus (1954). Similar work was done simultaneously in Belarus, Arkhangelsk Province, and Mari El Republic in partnership with researchers from Belorussian, Northern and Volga-Kama branches of All-Union Research Institute of Animal Raw Materials and Furs (now - Russian Research Institute of Game Management and Fur Farming). Based on the Institute's recommendations limited trapping started in the 1963-1964 winter season in Belarus and ten regions of the Russian Federation. Trapping and monitoring within the experimental areas continued until 1966. During the summer of 1966 on the Belarus experimental area (Berezina River within Minsk Province) 32 beavers were marked and released in the trapping area. Ten of them were then trapped during the following autumn-winter season. Recurrent trapping of animals in the same settlements during 2-3 seasons in a row and their marking confirmed that the places of kill trapped adults are taken by migrants from another settlement or from the periphery of the parental settlements.

This research indicates that removal of dominant animals enables younger individuals to realize their breeding potential earlier since before they did not have a reproductive opportunity due to their subordinate role in the family hierarchy. As a result there is an "unlocking" of natural population breeding inhibition mechanism. Interchangeability of breeding individuals appears during certain stages of population development: in the beginning of its formation (for example, after introduction of a breeding pair) the settlements are isolated, free areas for new settlements are abundant and strictly familial living and monogamy are the primary regulators of intraspecific relations. The mechanism of self-regulation is turned on as the population density increases and fewer favourable areas for dispersing young animals are available. In the Berezina River flood plain beaver settlements could be separated conditionally; there were many singletons (single adult beavers) inhabiting barely suitable areas, whereas in "young" populations settlements are sharply delineated. These peculiarities of the population dynamics formed the base of recommendations to limit the trapping to one adult beaver from a settlement and to restart trapping in the settlement only in the next hunting season. We recommended the above-noted method of trapping regulation based on the experience from the Kirov region and Belarus. Later Kudryashov (1980) conducted similar studies in the Oka River basin and came to the same conclusions.

Emelyanov (2012) suggests limiting trapping in a settlement until the first adult animal (male or female) is trapped. This will not negatively influence reproduction because another reproductive adult will replace the removed adult. In large settlements and in high density populations only one dominant female reproduces while the rate of non-reproducing mature females can reach 30\% (Litvinov, 2012; Vostokov, 2014). 
Initiating beaver trapping also allowed obtaining large amounts of biological material, which significantly widened knowledge about the population ecology of beavers. For the first time the method of defining the exact age of Eurasian beavers by analysing the layered structure of cementum deposits on longitudinal sections of molars was introduced, and the possibility of dividing youngsters into current year's young, yearlings and two-year-old by the level of pulp chamber occlusion was proven. Time limits of sexual maturation were clarified by analysing the presence of sperm cells in testis smear of the individuals 1.5-2 years old animals (Safonov, 1966, 1971). Knowledge on behaviour during the under-ice period that is least accessible for observation was significantly complemented. Beaver activity outside the rest site depends on the air temperature. At temperatures down to $-20^{\circ} \mathrm{C}$ beavers limit their activity to the settlement area where there are stocks of woody forage (the winter food cache) and temporary (reserve) dens. The presence of fresh bites on tails and skins of males and females (six animals out of 20 trapped within the research area in the Kirov Province in 1962-1963) indicates the possibility of interaction between animals from different settlements during winter. Under ice the beavers primarily move along paths near the shore apparently, in coastal ice cavities formed by water level fluctuation, which allow an adequate air resupply. This explains the success of traps installed under ice in coastal shoals or on the bottom rail of a doused vertical aspen frame near the den exit (Safonov, 1964, 1965). These observations contributed to the development and increase of efficacy of trapping methods.

Through the work of many zoologists, game biologists, nature reserve workers and game management workers the beaver population and range were restored in the USSR. However, scientifically based population management in the current social and economic conditions of the country is still not well coordinated. There is no denying that it is to some extent connected with the sharp decline in demand for furs in general (except for sable) on both international and national markets. This demand decline makes it necessary to take steps to develop and implement a population management system according to ecological priorities.

It is not productive to embrace the extreme position of describing the beaver as "invasive, alien species, most dangerous to natural ecosystems" (Khlyap et al., 2011). The Castoridae has a rich and diverse evolutionary history including during the Miocene and Pliocene when the number of known beaver genera reached 30 (Korth, 2001). Beavers were and continue to be natural components of wetland ecosystems and have evolved with these systems. To consider the two extant species of the genus Castor as harmful and alien for their native ecosystems is to neglect both their evolutionary history and our modern, scientific understanding of their ecological role in wetlands. What is different during our contemporary period is the presence of humans and human activity in these same ecosystems. The Eurasian beaver is a successfully restored ecosystem component (Halley et al., 2012) and the following questions need to be answered in order to develop sound population management protocols.

First, what is the possibility and viability of continuing work on restoring the former range of the beaver throughout Eurasia? Studies of fossil remains prove that the historical range of the Eurasian beaver was significantly wider than the modern one. At the beginning of the $20^{\text {th }}$ century Eurasian beavers were only found in few isolated refugia and their population was estimated to be 1200 individuals (Nolet \& Rosell, 1998). By the beginning of the $21^{\text {st }}$ century the beaver population in Eurasia was estimated to be over one million individuals (Halley et al., 2012). The range has also widened. Nevertheless, reintroduction is recommended for Scotland, England, Bulgaria and Italy (Nitsche, 2003). In Russia the translocation of Eurasian beavers were reduced to a minimum, and introductions of North American beavers have been stopped. The range of $C$. fiber is now naturally expanding and the population increasing. Under current conditions the correct system of population management is needed more than further reintroductions.

Second, how large is the problem of North American beavers that have become established in the range of the Eurasian beavers? During the period of the most intensive translocations the contact of ranges of $C$. fiber and $C$. canadensis was allowed. The validity of the species being present now is out of discussion (Durka et al., 2005; Helgen, 2005; Senn et al., 2014). North American beavers released in Finland have settled in the Leningrad Province and the Karelia Republic and now contact Eurasian beavers (Danilov et al., 2007). The consequences of the process are still not clear although their construction behaviours appear similar (Danilov \& Fyodorov, 2015). A similar situation was created in the Russian Far East (Khabarovsk Territory), and the effect of releasing beavers of two species is also not clarified. During the Worldwide Beaver Symposium in Helsinki, Zurowski (1982) stated the danger of combining ranges. I share this opinion because I believe that evolutionarily North American beavers are younger and more competitive than Eurasian beavers. Also, a similar situation is the example of the American mink superseding European mink.

The only example in which C. canadensis introduction could be justified is the species release in Kamchatka Peninsula and Sakhalin Island where it can survive in proper isolation that historically determined the formation of two independent species. First results of North American beavers release in Kamchatka were successful, especially in the Milkovsky District (Kamchatka River basin). Along with traditional woody forage beavers actively used endemic species: fragrant poplar (Figs. 1A-B), Chosenia sp. (Fig. 2), and Sakhalin willow. It is important to consider that beavers were released into "salmon" rivers where brown bears ( $U r$ - 

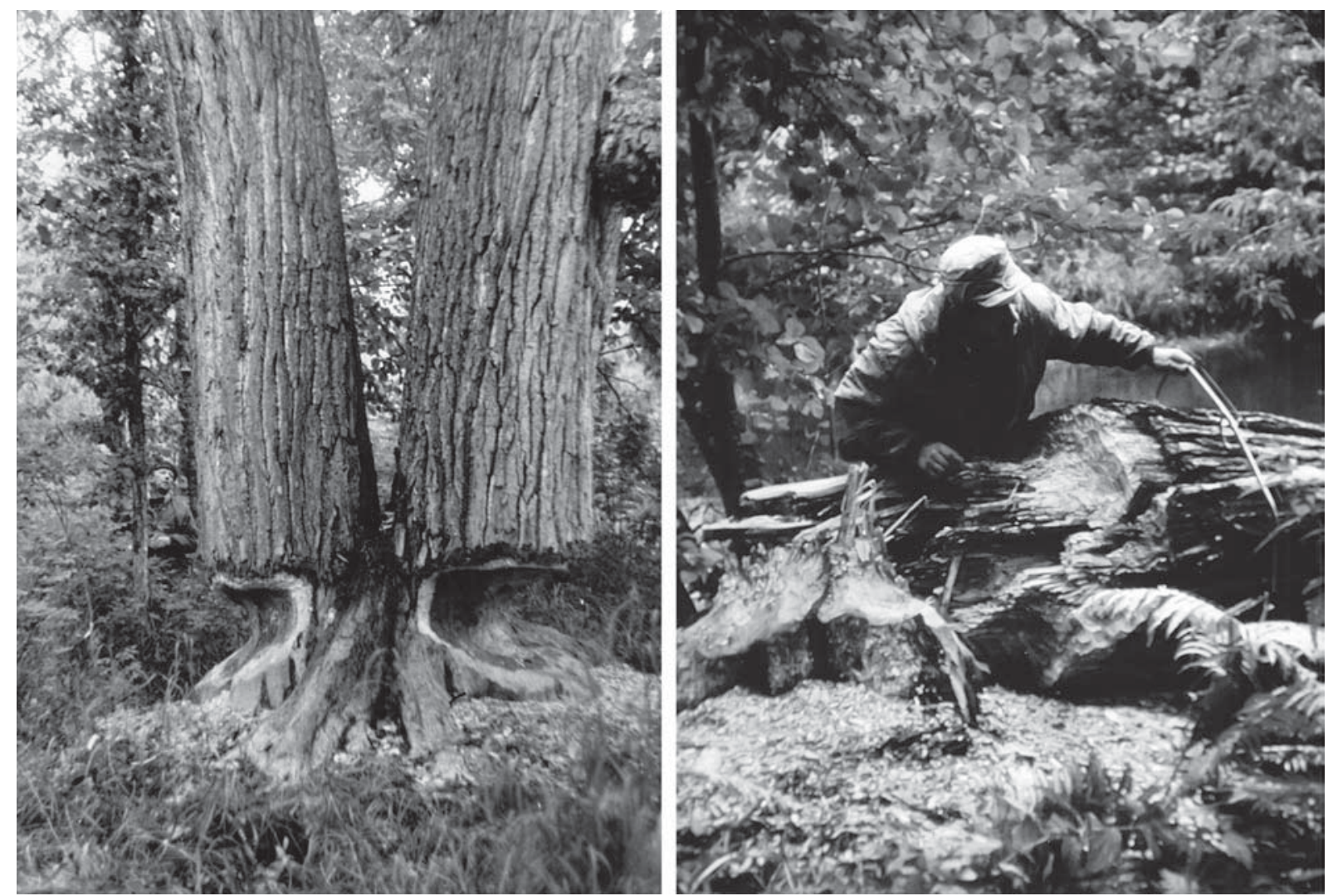

Fig. 1. Cuts of poplar Populus suaveolens made by beavers Castor canadensis. Hereinafter - Kamchatka River, Kamchatka Peninsula. Photographed by author, September 1998.

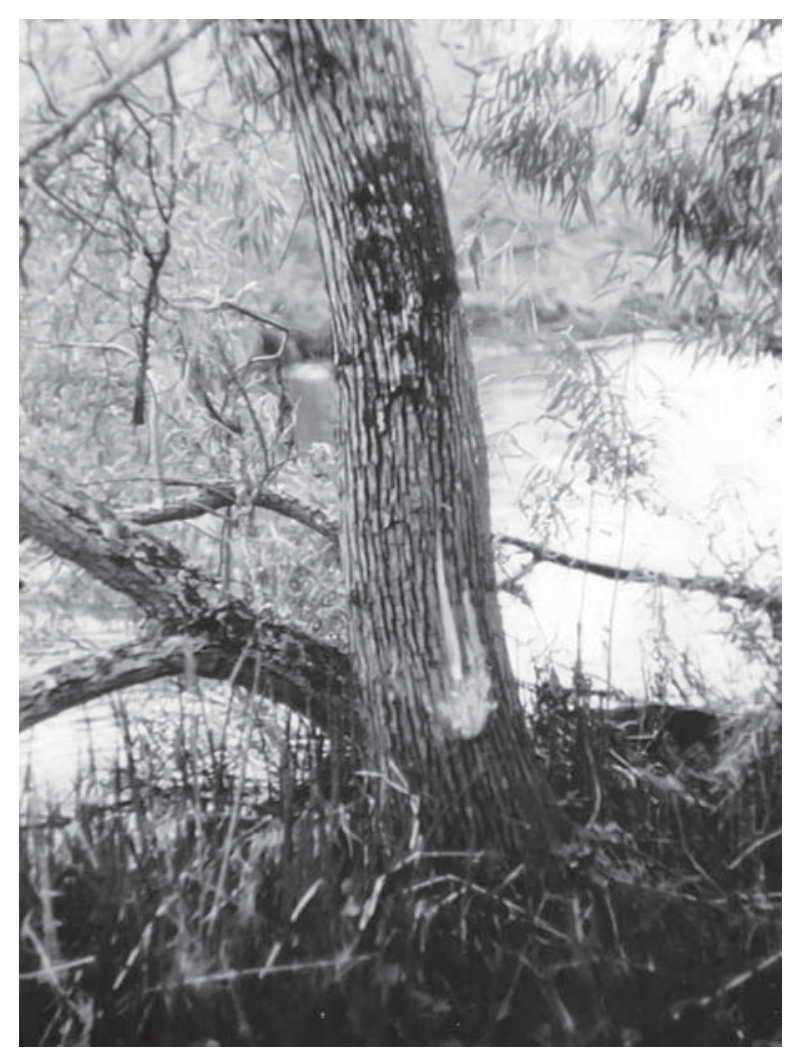

Fig. 2. Beaver cuts on a Chosenia tree. sus arctos) concentrate during the whole spawning season. In the first year after the release we did not find any signs of bear predation on beavers. In the consecutive years digging beaver houses and dens (Fig. 3), and bear footprints on feedlots of beavers became common. There is no data on current numbers of North American beavers in Kamchatka and their relations with bears. The study of the interspecific peculiarities of behaviour of beavers in the contact areas and their relations with local fauna, needs to be done (Oleynikov, 2013).

Third, what roll should the subspecific division of the Eurasian beaver play in any management system? It is customary to distinguish eight subspecies - C. $f$. fiber Linnaeus, 1758, C.f. albicus Matschie, 1907, C.f. galliae E. Geoffroy, 1803, C. f. belorussicus Lavrov, 1981, C. f. orientoeuropaeus Lavrov, 1981, C. f. pohlei Serebrennikov, 1929, C.f. birulai Serebrennikov, 1929, and C.f. tuvinicus Lavrov, 1969 - which were formed in conditions of isolated habitats. During the process of range restoration and reintroductions increased mixing of subspecies is inevitable. This also happened in North America with $C$. canadensis, where historically more than 20 subspecies were distinguished, and subspecies mixing occurred during reintroductions. We have to clarify the role of isolated populations and isolated gene pools (subspecies) in the mixing during natural resettlement or introduction. I recommend continuing the work initiated by Milishnikov et al. (1994), Milish- 


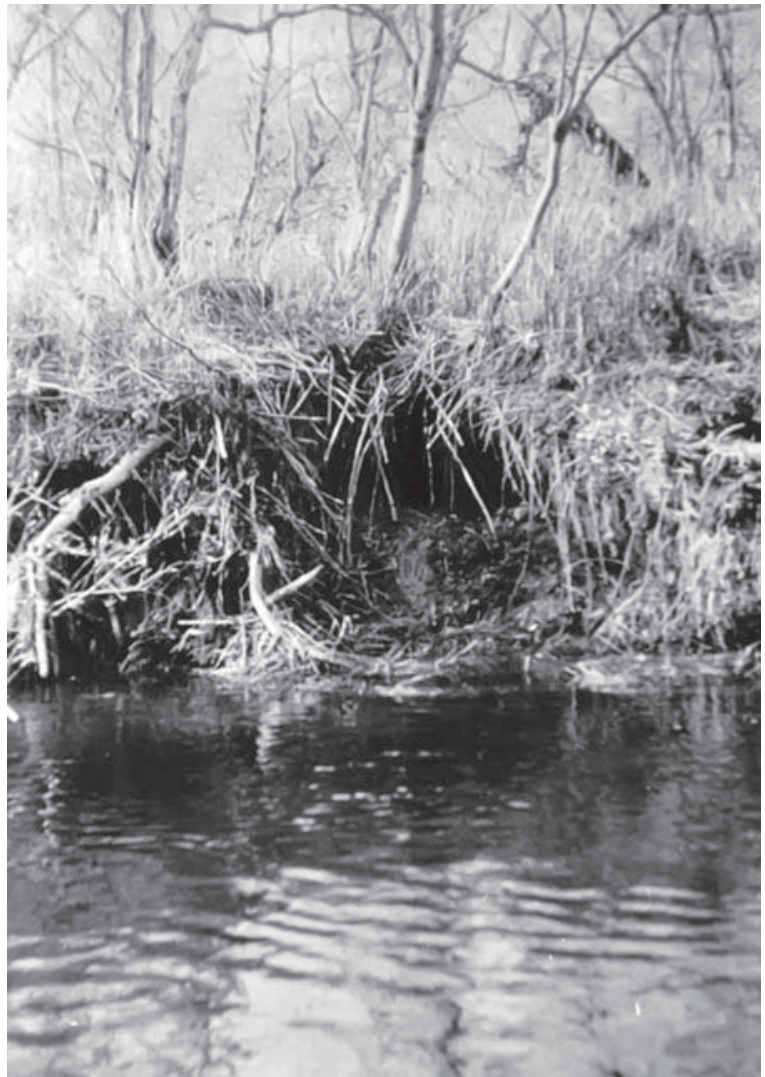

Fig. 3. Lodge of introduced beaver has been dug out by a brown bear.

nikov \& Saveljev (2001), and Saveljev (2003). Because low genetic diversity (bottleneck effect) can be a cause of a stable depressed population state, it is more rational to try to manage the process on the basis of special studies than to take almost impossible to enforce measures of protecting isolation during natural resettlement.

Fourth, how can more robust and accurate official population estimates be obtained? Current official data on the size of the beaver population in Russia and Belarus may at best claim to reveal a trend and not the accurate size of the population. The error in census data exceeds the level of annual population growth. According to fur-experts (Zarubin et al., 2015a,b), the current annual bag in Russia exceeds 100,000 beavers. In Belarus, in the middle of the 1980's, beaver trapping accounted for about 2,000 animals (out of a population of 30,000$)$ and was gradually increased to 3,500 animals from 1987-2009 when the total population was estimated to be 80,000 (Litvinov, 2012). An average of $20-30 \%$ of the population as the annual trapping take (16,000-20,000 beavers in Belarus) will not decrease reproduction (Vostokov, 2014). However, trapping should be differentiated according to conditions of certain populations: from a total ban to unlimited trapping. The most rational approach to organize the economic use of beavers is to insure hunters' financial interests by assigning hunting areas that include the right to inherit.
A positive experience of beaver management by securing inheritable and officially registered hunting grounds is known in Canada (Novak, 1987). In the current social and economic conditions in Russia, when it is difficult to rely on state or cooperative enterprises, this method becomes especially important in the areas inhabited by indigenous ethnic groups. The support of trapping as a traditional life style will provide stable occupation, and insure the survival of ethnic identity, while at the same time preserving natural ecosystems.

\section{References}

Barabash-Nikiforov I.I., Dezhkin V.V. \& Dyakov Yu.V. 1961. [Beavers of Don basin. Ecology and economical issues (monographic sketch)] // Trudy Khoperskogo Goszapovednika. Vol.5. P.3-115 [in Russian].

Borodina M.A. 1960. [Methods of economical use of European beaver in connection with its ecological peculiarities] // Trudy Okskogo Goszapovednika. Vol.3 P.41-76 [in Russian].

Boyce M.S. 1981. Beaver life-history responses to exploitation // Journal of Applied Ecology. Vol.18. No.3. P.749753.

Danilov P.I. \& Fyodorov F.V. 2015. Comparative characteristics of the building activity of Canadian and European beavers in northern European Russia // Russian Journal of Ecology. Vol.46. No.3. P.272-278.

Danilov P.I., Kanshiev V.Ya. \& Fyodorov F.V. 2007. [Beavers of the Russian European North]. Moscow: Nauka. 200 p. [in Russian].

Durka W., Babik W., Ducroz J.-F., Heidecke D., Rosell F., Samjaa R., Saveljev A., Stubbe A., Ulevicius A. \& Stubbe M. 2005. Mitochondrial phylogeography of the Eurasian beaver Castor fiber L. // Molecular Ecology. Vol.14. No.12. P.3843-3856.

Emelyanov A.V. 2012. [System Research of Ecology and Resources Management of European Beaver]. Tambov: Tambov State University. 93 p. [in Russian].

Halley D., Rosell F. \& Saveljev A. 2012. Population and distribution of Eurasian beaver (Castor fiber) // Baltic Forestry. Vol.18. No.1. P.168-175.

Helgen K.M. 2005. Family Castoridae // Wilson D.E. \& Reeder D.M. (eds.). Mammals Species of the World. A Taxonomic and Geographic Reference. Third edition. Vol.2. Baltimore: Johns Hopkins University Press. P.842843.

Korth W.W. 2001. Comments on the systematics and classification of the beavers (Rodentia, Castoridae) // Journal of Mammalian Evolution. Vol.8. No.4. P.279-296.

Kudryashov V.S. 1980. [Economical use of European beaver stock] // Nikiforov L.P. (ed.). Biologicheskiye Osnovy Okhotnichyego Dela. Moskva. P.45-56 [in Russian].

Khlyap L.A., Warshavsky A.A. \& Bobrov V.V. 2011. Diversity of alien mammal species in different regions of Russia // Russian Journal of Biological Invasions. Vol.2. No.4. P.293-299.

Larson J.S. \& Gunson J.R. 1983. Status of the beaver in North America // Acta Zoologica Fennica. No.174. P.9193. 
Lavrov L.S. 1983. Evolutionary development of the Castor and taxonomy of the contemporary beavers of Eurasia // Acta Zoologica Fennica. No.174. P.87-90.

Lavsund S. 1977. Bäverns utbredningshistoria och nuverande förekomst i Sverige // Rapp. och uppsats Inst. scogszool. Skogshogsk. No.26. P.8-12.

Litvinov V.F., Yatusevich A.I., Kozlo P.G., Stavrovskiy D.D., Yanuta G.G., Karasev N.F., Litvinov A.V. \& Kozorez A.I. 2012. [Population Ecology of Beaver]. Vitebsk: VGAVM. 256 p. [in Russian].

Milishnikov A.N., Likhnova O.A., Nikonova O.A., Lavrov V.L. \& Orlov V.N. 1994. [Allozyme variability of European beaver $C$. fiber L. 1758 (Castoridae, Rodentia) from Voronezhsky State Reserve] // Genetika. Vol.30. No.4. P.529-534 [in Russian, with English summary].

Milishnikov A.N. \& Saveljev A.P. 2001. Genetic divergence and similarity of introduced populations of European beaver (Castor fiber L., 1758) from Kirov and Novosibirsk oblasts of Russia // Russian Journal of Genetics. Vol.37. No.1. P.108-111.

Nitsche K.-A. 2003. Biber. Schutz und Probleme. Moeglichkeiten und Massnahmen zur Konfliktminimirung. Dessau: Eigenverlag. 52 p.

Nolet B.A. \& Rosell F. 1998. Comeback of the beaver Castor fiber: an overview of old and new conservation problems // Biological Conservation. Vol.83. P.165-173.

Novak M. 1987. Beaver // Wild Furbearer Management and Conservation in North America. Ontario: Ministry of Natural Resources. P.283-312.

Odum E. 1975. [The Fundamentals of Ecology]. Moskva: Mir. 740 p. [in Russian].

Oleynikov A.Yu. 2013. Distribution of native and introduced semiaquatic mammals in Sikhote-Alin // Russian Journal of Biological Invasions. Vol.4. No.3. P.180-189.

Owens R. 1968. Beaver damage in Alabama // Forest Farmer. Vol.28. No.3. P.12-13.

Parsons G. \& Brown M. 1978. Effect of a four-year closure of trapping season for beaver in Fulton County // New York Fish and Game Journal. Vol.25. No.1. P.23-30.

Safonov V.G. 1962. [Before beaver trapping] // Okhota i Okhotnichye Khozyaistvo. No.2. P.24-27 [in Russian].

Safonov V.G. 1964. [Results of experimental trapping of beavers for pelts] // Sbornik Nauchno-Tekhnicheskoi Informatsii Vsesoyuznogo Nauchno-Issledovatelskogo Instituta Zhivotnogo Syrya i Pushniny, Kirov. Vol.10. P.42-51 [in Russian].

Safonov V.G. 1965. [Some peculiarities of beaver ecology during winter] // Sbornik Nauchno-Tekhnicheskoi Informatsii Vsesoyuznogo Nauchno-Issledovatelskogo Instituta Zhivotnogo Syrya i Pushniny, Kirov. Vol.12. P.2635 [in Russian].
Safonov V.G. 1966. [Morphological peculiarities and structure of beaver populations] // Byulleten Moskovskogo Obshchestva Ispytatelei Prirody. Otdel Biologicheskii. Vol.71. No.4. P.5-19 [in Russian, with English summary].

Safonov V.G. 1971. [Materials on reproduction biology of beaver in European part of USSR] // Trudy Kirovskogo Selskokhozyaistvennogo Instituta. Vol.28. P.25-39 [in Russian].

Safonov V.G. \& Semyonov B.T. 1962. [Ecological ground and organisational forms of economical use of beaver] // Sbornik Nauchno-Tekhnicheskoi Informatsii Vsesoyuznogo Nauchno-Issledovatelskogo Instituta Zhivotnogo Syrya i Pushniny, Kirov. Vol.4. P.3-16 [in Russian].

Saveljev A.P. 2003. [Biological Peculiarities of Aboriginal and Artificially Created Beaver Populations in Eurasia and Their Significance for the Resource Management Strategy]. Dissertatsiya Doktora Biologicheskikh Nauk [Dr.Sci Dissertation in Zoology]. Kirov: Russian Research Institute of Game Management and Fur Farming. 201 p. [in Russian].

Senn H., Ogden R., Frosch C., Syrùèková A., CampbellPalmer R., Munclinger P., Durka W., Kraus R., Saveljev A.P., Nowak C., Stubbe A., Stubbe M., Michaux J., Lavrov V., Samiya R., Ulevicius A. \& Rosell F. 2014. Nuclear and mitochondrial genetic structure in the Eurasian beaver (Castor fiber) - implications for future reintroductions // Evolutionary Applications. Vol.7. No.6. P.645-662.

Vostokov E.K. 2014. [Beaver in Belarus]. Minsk: Pravo i Ekonomika. 222 p. [in Russian].

Zarubin B.E., Kolokolchikova M.V., Makarov V.A. \& Shevnina M.S. 2015a. [Beaver (Castor fiber) game bag in Kirov region: results of monitoring] // Agrarian Science of Euro-North-East. No.6. P.70-74 [in Russian, with English summary].

Zarubin B.E., Makarov V.A. \& Safonov V.G. 2015b. Current status of the beaver fur market in Russia // Beavers from genetic variation to landscape-level effects in ecosystem. Book of Abstracts 7th International Beaver Symposium, 14-17 September 2015, Voronezh, Russia. P.72.

Zharkov I.V. 1968. [Structure and Dynamics of Mammal Populations by the Example of Beaver in USSR]. Avtoreferat Dissertatsii Doktora Biologicheskikh Nauk [Abstract of Dr.Sci Dissertation in Zoology]. Leningrad: Zoological Institute AN USSR. 42 p. [in Russian].

Zurowski W. 1983. Worldwide beaver Symposium, Helsinki, 1982: Opening remarks // Acta Zoologica Fennica. No.174. P.85-86. 